\title{
PHYSICAL, MECHANICAL AND AERODYNAMIC PROPERTIES OF SOME GRAINS AS RELATED TO DESIGN OF MECHANICAL SEPARATING SYSTEMS. \\ Abd El-Rahman, A. A. ${ }^{1}$; Magda. M. A. Mosa ${ }^{1}$ and H. E. Hassan ${ }^{2}$ \\ 1- Agric. Eng. Res. Institute, Agric. Res. Center, Dokki, Egypt. \\ 2- Inst. of Laser Enhanced Sc. (NILES), Cairo Univ., Egypt.
}

\begin{abstract}
Light projection area and some engineering properties for some grains (paddy rice and broad bean) were determined to assess their effectiveness on grain separation process. The main results in this study could be summarized as follows:1 - It is possible to use light projection area directly for paddy rice and broad bean grains instead of mathematical surface area. 2- The hole dimensions of sieves were determined, in case of the round sieves, the diameters proper of holes were 8.00 and $14.5 \mathrm{~mm}$. While, the distances between two holes were 6.00 and $10.7 \mathrm{~mm}$ ) for rice and broad beans, respectively. In case of slot holes of sieves, the dimensions of hole were $(8 \times 3.5 \mathrm{~mm})$ and $(14.5 \times 10.5 \mathrm{~mm})$ while the distances between two holes were $(7.5 \times 2.5 \mathrm{~mm})$ and $(18.25 \times 5.0 \mathrm{~mm})$ for rice and broad bean, respectively. 3- The mean terminal velocity values were 20 and $75 \mathrm{~m} / \mathrm{s}$ for paddy rice and broad bean, respectively. But, for the impurities of grains, the mean terminal velocity values were 5 and $15 \mathrm{~m} / \mathrm{s}$, respectively. 4- The friction angle (slope angle) of silo and hopper were 23 and $17^{\circ}$ for rice and broad bean, respectively using steel as material for silo and hopper. 5 - The slop angle of sieves towards horizontal plan was $5^{\circ}$ for rice and $7^{\circ}$ for broad bean.
\end{abstract}

\section{INTRODUCTION}

Rice is life for thousands of millions of people and it is the second important crop after Wheat in Human Food. It is deeply embedded in the cultural heritage of their societies. It is the staple food for more than half of the world population. Broad beans are an annual legume known botanically as Vicia Faba L. The crop is one of the major winter vegetable crops grown in Egypt, for local consumption and export. It is also, a popular member of the leguminous family, which mostly consumed as green shelled, dried canned and mainly grown pods and dry grains.

Ministry of Agriculture and Land Reclamation (2013) reported that the cultivated area of rice and broad beans in Egypt was about 1472139, and 105000 feddans, it was produced about 5896577 tons and 1006000 ardbs, respectively. Rice and Broad beans farm yield in 2012 - 2013 were 4.005 tons and 9.58 ardbs per Fadden, respectively with total production about 5.9 million tons/ year1.01 million ardbs / year, respectively.

According to the quality standard for exported crops and their products (Regrulions of Trade Ministry, 1992), rice for export must be clean, possessing its natural smell, contain no live insects, display the required degree of whiteness, display not more than percentage by blemishes permitted for its category. Dried broad beans denotes the species Vicia faba only for export must be of a single variety, fully mature of uniform size, 
clean, containing no extraneous seeds or foreign matter, characterized by a moisture content not exceeding $14 \%$ and not more than $5 \%$ of them broken of split or divested of their skins.

Mohsenin (1986) mentioned that for small objects such as seeds, the outline of projection of each sample could be traced using a photographic enlarger. The seed is placed on the plane were the negative is positioned, turned so that its shadow covers the largest area. Then, the in larger is focused a sharp boundary. A millimeter scale is also traced along with the seed image. The seed is thin turned to show a minimum projection area whose long dimension is equal to the long dimension of the maximum projection area.

1- Head of Researcher, Agric. Eng. Res. Institute, Agric. Res. Center, Dokki, Egypt.

2- Senior Researcher, Agric. Eng. Res. Institute, Agric. Res. Center, Dokki, Egypt.

3- Prof., Dr., Nat. Inst. of Laser Enhanced Sc. (NILES), Cairo Univ., Egypt.

Dilday (1987) studied the effect of moisture content on the rice breakage during the milling process. He used samples with moisture content of 12 to $16 \%$ and concluded that rice breakage decreased with increase of paddy moisture content.

Natsuga et al. (1992) mentioned that the standard deviation of differences among repetitions (SDD) in measured moisture content of damp rough rice $(0.32 \%)$ and the SDD in measured moisture content of damp brown rice $(0.29 \%)$ were larger than those of dried rice. The SDD data indicated that high-moisture rice had a large moisture distribution.

Awady and Sayed (1994) stated that when air stream is used for separation of product from its associated foreign materials, knowledge of terminal velocity of all particles is involved. For these reasons, terminal velocity has been used as an important aerodynamic characteristic of materials such applications as pneumatic conveying and separation from foreign materials.

El-Raie et al. (1996) determined the terminal velocity of wheat, rice, and barley. They found that the terminal velocity ranged from5.85 to 9.705 $\mathrm{m} / \mathrm{s}$ for wheat varieties, from 7.888 to $8.548 \mathrm{~m} / \mathrm{s}$ for rice varieties and from 7.49 to $9.953 \mathrm{~m} / \mathrm{s}$ for barely varieties.

Helmy (1995) determined the static coefficient of fraction (SFC) of some Egyptian cereal varieties by using (a) Five different friction surfaces of glass; galvanized metal; plywood; plastic and stainless steel (b) Four different levels of grain moisture content 11, 12,13 and 14 (w.b) and (c) Four different cereal sample masses of $75,100,125$ and $150 \mathrm{~g}$. Generally, the increase of grain moisture contents inversed the static friction coefficient significantly. The highest values of static friction coefficient (SFC) were obtained using plywood sheet in all cases, while the lowest values of static friction coefficient were obtained by using stainless steel sheet at the same condition.

Molenda et al. (2002) reported that the friction between seed and a surface area has an influence on the movement of particles on oscillating 
conveyors, cleaning using oscillating sieves and loading and unloading operations.

Zewdu (2004) reported the importance of difference in size and density during separating particles by segregating on gravity tables. Size, shape and density are important in the separation of seed from undesirable materials on oscillating chaffers, because of knowledge on physical properties of seeds is of paramount importance in designing equipment for handling, storing or processing.

Asoegwu et al. (2006) investigated physical properties of African oil bean seed and reported the dependence of these properties against mass of the grain. However, information on the moisture-dependent physical properties of grass pea seeds is nonexistent in literature.

Simonian et al. (2006) said that an increase in moisture content of grain and straw contributes to a decrease in cleaning efficiency. In view of this, several studies have been conducted on the physical properties such as size, shape, bulk density, true density, porosity, angle of repose and coefficient of static and dynamic friction of different cereals and beans in relation to moisture content.

The aim of this study was to investigate the following points:

1- Determination of light projection area and some physical, mechanical and aerodynamic properties for Rice and Broad bean grains, and its effect on separation and cleaning process.

2- To asses the proper shape and size of sieves holes used for threshing process of the studied grains.

\section{MATERIALS AND METHODS}

The experimental work was conducted at the Agricultural Engineering Research Institute and laboratory of laser application in Agricultural Engineering at National Institute of Laser Enhanced Science (NILES), Cairo University in 2012. The goal of study was to determine projection area using visible laser and main physical, mechanical and aerodynamic properties for two types of grain (Rice and Broad bean) using a laboratory measurements and mathematical equations. These properties were determined to know it's effectiveness on grain separation and cleaning process.

1-Crop used in investigation, a random samples from two types of grains were obtained namely, rice grains (Giza 176 variety) and broad bean (Giza 40 variety). After rejecting damaged grains, stones, and other foreign materials by manual method, each grain main dimension were measured to mathematically calculate the surface areas of each grain type.

2-Physical properties of grain, grain size was determined by measuring axis as length (L), width (W) and thickness $(T)$ by using a digital caliber. The data were appointed to determine shape and size of the studied types of grain at initial moisture content of $14.1 \%$ w.b for rice and $13.2 \%$ w.b for bean . 
Mathematical equations for determination of various grains shapes have bean used, based on a large number of measurements, to express the correlation between the three principal dimensions of grains. The following equations were used to calculate the value of the mentioned properties, (ElRaie, 1987).

Volume of grain $(\mathrm{V}, \mathrm{mm} 3)$ :

$$
\mathrm{V}=\frac{\pi}{6} \mathrm{LWT}, \mathrm{mm}^{3}
$$

Sphericity of grain $(\mathrm{S}, \%)$ :

$$
\mathrm{S} \%=\frac{L}{\mathrm{~W}}
$$

(2) (Mohsenin, 1986)

Frontal surface area $\left(\mathbf{A f}, \mathrm{mm}^{2}\right)$ :

$$
\text { Af }=\frac{\pi}{4} \mathrm{LW}, \mathrm{mm}^{2}
$$

Projection area of grains: projection surface area of grain was also determined using laser beam as calculated by (El-Raie et al., 2004).

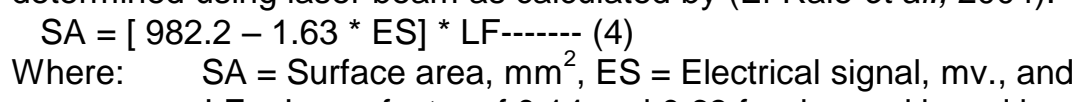

$\begin{aligned} & \mathrm{LF}=\mathrm{Laser} \text { factor of } 0.14 \text { and } 0.63 \text { for rice } \\ & \text { 3-Mechanical and aerodynamic properties of grain }\end{aligned}$

a- Terminal velocity of grain and pieces of straw for rice and broad bean were measured by the floating apparatus.

b-Friction angle, considering of the coefficient of friction between granular materials is equal to the tangent of the angle of internal friction for the materials, according to

Chakraverty (1987).

c-Slop angle of the sieve toward horizontal plan was measured.

4-Parameters affecting selection of screen, affecting parameters of sieves selection were calculated as follows according to El-Raie (1981):

- Productivity of sieve used in the cleaning and sorting process was calculated as follows:

Where: $Q$ : productivity of sieve $(\mathrm{kg} / \mathrm{h})$,

$$
Q=q_{F}{ }^{*} F_{S}=q_{F}{ }^{*} B_{S}{ }^{*} L_{s}=q_{B}{ }^{*} B_{S}
$$

$$
\begin{aligned}
& q_{F}: \text { specific load of unit area of the sieve per unit time, }(\mathrm{kg} / \mathrm{h}) / \mathrm{cm}^{2} \\
& \mathrm{q}_{\mathrm{B}} \text { : specific loading per unit width of the sieve, }(\mathrm{kg} / \mathrm{h}) / \mathrm{cm}
\end{aligned}
$$

$F_{\mathrm{s}}$ : total surface area of screen, $\mathrm{cm}^{2}$,

$B_{s}:$ width of the screen, dm, $\left(500 \mathrm{~mm}>B_{s}>130 \mathrm{~mm}\right)$,

$L_{s}$ : length of the screen, dm ( $\left.2500 \mathrm{~mm}>L_{s}>600 \mathrm{~mm}\right)$, and

$L_{s} / B_{s}$ : is the between length and width of screen, $\left(4.0>L_{s} / B_{s}>1.0\right)$

- The ideal distribution of holes may be evaluated by coefficient of live area $(\mu)$ according to the following function:-

$$
\mu=F_{o} / F
$$

Where: $F_{0}$ : is the total area of the holes on the sieve, $\mathrm{cm}^{2}$ and $F$ : is the total area of the sieve sheet, $\mathrm{cm}^{2}$

- For round holes, the ideal distribution of holes may be evaluated by coefficient of live area $(\mu)$ according the following equation: 


$$
\mu=\frac{\pi \mathrm{r}^{2}}{2 \sqrt{3}(\mathrm{r}+\mathrm{m})^{2}}
$$

Where: $2 r=d$ : is the diameter of the hole, $(0.9 \leq \sqrt{d})$

$2 m$ : is the distance between two neighboring holes, $(2 m \leq \sqrt{2 r})$ - For slot holes, the ideal distribution of holes may be evaluated by coefficient of live area $(\mu)$ according the following equation:

$$
\mu=\frac{h 1 * h 2}{(h 1+e 1)(h 2+e 2)}
$$

Where: $\mathrm{h} 1$ : is the length of the hole, $\mathrm{mm}$ and $\mathrm{h} 2$ : is the width of the hole, $\mathrm{mm}$

$$
\frac{14 \mathrm{~h} 2}{1+0.2 \mathrm{~h} 2} \leq \mathrm{h} 1 \leq \frac{20 \mathrm{~h} 2}{1+0.3 \mathrm{~h} 2}
$$

$\mathrm{e} 1$ and $\mathrm{e} 2$ : is the width of pore spaces between the neighboring holes, $(\mathrm{e} 1=1.5 \sim 3.0 \mathrm{~mm}$ at $\mathrm{h} 2=1.25 \sim 3.5 \mathrm{~mm}$ and $1.00+0.35 \mathrm{~h} 2 \leq \mathrm{e} 2 \leq 1.35+$ $0.42 \mathrm{~h} 2)$

Instruments:

Floating apparatus specification, source of manufacture (Japan). Electricity source of power, Work theory by vacuum, maximum measuring is $150 \mathrm{~m} / \mathrm{s}$ and accuracy is $0.1 \mathrm{~m} / \mathrm{s}$.

The wind tunnel shutter of grain (the floating apparatus) was used for measuring the terminal velocity of grain and impurities Model ( $\mathrm{S}$ ).

Digital venire caliper, it has an accuracy of $0.05 \mathrm{~mm}$. It was used to measure the dimensions of individual grains.

Electronic balance: An electronic balance (made by Japan) was used for weighing samples before and after cleaning. Its scale ranged from 0 to $5 \mathrm{~kg}$ max., with accuracy of $0.01 \mathrm{~g}$.

Moisture content meter of grain, it has the following specifications: 1 - The moisture tester model SP - 1D, 2-Manufactured by Japan, 3- Accuracy is $\mp$ $0.5 \%$, 4- The power is $220 \mathrm{~V}$, and 5- The ambient working temperature from 0 to $40^{\circ} \mathrm{C}$.

Grain hardness, hardness of the grains was tested using hardness tester (model 174886 kiya seisakusho LTD). The hardness value of each sample was recorded in Newton.

Apparatus of measurin projection area: an opto-electronic apparatus was manufactured and developed to measure projection area of grains. The opto - electronic apparatus are consists of the following main parts: 1- Stand holder, 2- helium-neon laser ( $\mathrm{He}-\mathrm{Ne}$ ) with wavelength $632.8 \mathrm{~nm}$ with power 8 $\mathrm{mW}$, 3- Photos voltaic cell, 4- Optical bench, and Avometer (El-Raie et al., 2004). It was used to measure the projection area of grain, with measure grain shadow area and subtract it from a known light area. An optoelectronic apparatus with calibrated using measuring grain prints.

Statistical analysis:

The obtained data were subjected to statistical analysis according to procedures outlined by Gomez and Gomas ( 1984). 


\section{RESULTES AND DISCUSSION}

This section determines physical, mechanical and aerodynamic properties of paddy rice ( Giza 167 variety), and broad beans (Giza 40 variety) as a following:

\section{1- Physical properties of grains :}

Some Physical and mechanical properties of different grains were listed in Table (1).

Grains dimensions were used in the experiments are shown in Table (1). The range of the minimum and maximum dimensions of paddy rice and broad bean grains are as following:

Length $(\mathrm{L})=(6.1-7.7)$ and $(10.6-14.2) \mathrm{mm}$, width $(\mathrm{W})=(2.2-3.4)$ and $(8.3-10.3) \mathrm{mm}$, thickness $(\mathrm{T})=(1.85-2.4)$ and $(6.8-8.2) \mathrm{mm}$, and mass of 1000 grains $=(13-18)$ and $(498-611)$ g., respectively. The average of volume and bulk density were ( $22.99-505.10) \mathrm{mm}^{3}$ and (768 and 1189 ) $\mathrm{kg} / \mathrm{m}^{3}$ for rice and broad bean grains, respectively. Also the moisture content of the same grain was 14.1 and 13.2 w.b. \%, respectively. The sphericity ( $\mathrm{S}, \%)$ of rice and faba bean grains was calculated and it was 52.49 and $75.31 \%$, respectively. I f ilt was less than 0.9 , the grain belongs to the oblate group.( Buyanov and Voronyuk., 1985 ). The shape and size of grains affect the processes involved in many applications such as grading ,sorting and so on.

The frequency distribution curves for rice and broad bean grains for their length (L), width (W) and thickness (T) are shown in Fig.(1). The frequency distribution curves show a trand towards normal distribution. From Fig. (1) results showed that the percentage of frequency is 45 and $34 \%$ for paddy rice and broad bean, at mean grain length was about 12.84 and 6.63 $\mathrm{mm}$. Meanwhile, for mean grains width it was about 3.04 and $9.65 \mathrm{~mm}$, the percentage of frequency is 55 and $35 \%$ for rice and broad bean grains , respectively. For mean grains thickness of about 2.16 and $7.72 \mathrm{~mm}$, the percentage of frequency is 80 and $34 \%$ for rice and broad bean grains, respectively.

2- Mechanical and aerodynamic properties of grains :

From Table (2) the average of hardness of the grains were ( 39 and $225, \mathrm{~N})$, for paddy rice and broad bean grains, respectively. The terminal velocity of grains (G.T.V), and terminal velocity of impurities (I.T.V.) were ( 20 and 75 ) and ( 5 and 15 ) $\mathrm{m} / \mathrm{s}$, respectively. In the same table the friction angle (slope angle) of hopper $(\varphi)$ by using steel surface as material for hopper was ( 23 and 17 ) degree, and the slope angle of the sieve toward horizontal plan (B) was ( 5 and 7 ) degree, and for rice and broad bean grains, respectively.

\section{3- Statistical analysis:}

The statistical analysis of physical, mechanical, and aerodynamic properties of the studied grains were calculated and tabulated in Tables (1) and (2) such as the standard deviation (SD) and coefficient of variance (CV). The statistical values were allowed under this experimented work. 
Table (1): Statistical analysis for physical properties of the studied grains.

\begin{tabular}{|c|c|c|c|c|c|c|c|c|}
\hline $\begin{array}{l}\text { Main } \\
\text { statistical } \\
\text { Values }\end{array}$ & $\begin{array}{l}\text { Length } \\
\text { (L), mm }\end{array}$ & $\begin{array}{l}\text { Width } \\
\text { (W), } \\
\text { mm }\end{array}$ & $\begin{array}{l}\text { Thick. } \\
\text { (T), } \\
\text { mm }\end{array}$ & $\mathrm{S}, \%$ & $\begin{array}{c}\text { Mass of } \\
1000 \\
\text { grains, } \\
\mathrm{g}\end{array}$ & $\begin{array}{l}\text { Af, } \\
\text { mm }^{2}\end{array}$ & $\begin{array}{c}\mathrm{V}, \\
\mathrm{mm}^{3}\end{array}$ & $\begin{array}{l}\mathrm{Bd}, \\
\mathrm{g} / \mathrm{mm}^{3}\end{array}$ \\
\hline \multicolumn{9}{|c|}{ Paddy rice, Giza 176 variety } \\
\hline Rang. & $6.1-7.7$ & 2.2-3.4 & $\begin{array}{c}1.85- \\
2.4\end{array}$ & $\begin{array}{c}46.3- \\
57.7 \\
\end{array}$ & $13-18$ & $\begin{array}{l}10.88- \\
18.68 \\
\end{array}$ & $\begin{array}{l}13.42- \\
26.90\end{array}$ & $\begin{array}{c}0.000483- \\
0.001341 \\
\end{array}$ \\
\hline Ave. & 6.63 & 3.046 & 2.161 & 52.488 & 15 & 15.882 & 22.994 & 0.000696 \\
\hline S.D & 0.503 & 0.339 & 0.156 & 3.616 & 0.002 & 2.317 & 4.169 & 0.000238 \\
\hline C.V, $\%$ & 0.076 & 0.111 & 0.072 & 0.069 & 0.107 & 0.146 & 0.181 & 0.342063 \\
\hline \multicolumn{9}{|c|}{ Broad bean Giza 40 variety } \\
\hline Rang. & $\begin{array}{l}10.6- \\
14.2 \\
\end{array}$ & $\begin{array}{l}8.3- \\
10.3 \\
\end{array}$ & $6.8-8.2$ & $\begin{array}{l}70.6- \\
85.7 \\
\end{array}$ & $498-611$ & $\begin{array}{l}76.9- \\
114.8 \\
\end{array}$ & $\begin{array}{l}348.5- \\
627.6 \\
\end{array}$ & \begin{tabular}{|c|}
$0.000813-$ \\
0.001687 \\
\end{tabular} \\
\hline Ave. & 12.84 & 9.65 & 7.72 & 75.310 & 577 & 97.725 & 505.100 & 0.001190 \\
\hline S.D & 1.392 & 0.717 & 0.461 & 4.913 & 0.033 & 16.148 & 100.750 & 0.000272 \\
\hline C.V,\% & 0.108 & 0.074 & 0.060 & 0.065 & 0.058 & 0.165 & 0.199 & 0.228955 \\
\hline
\end{tabular}

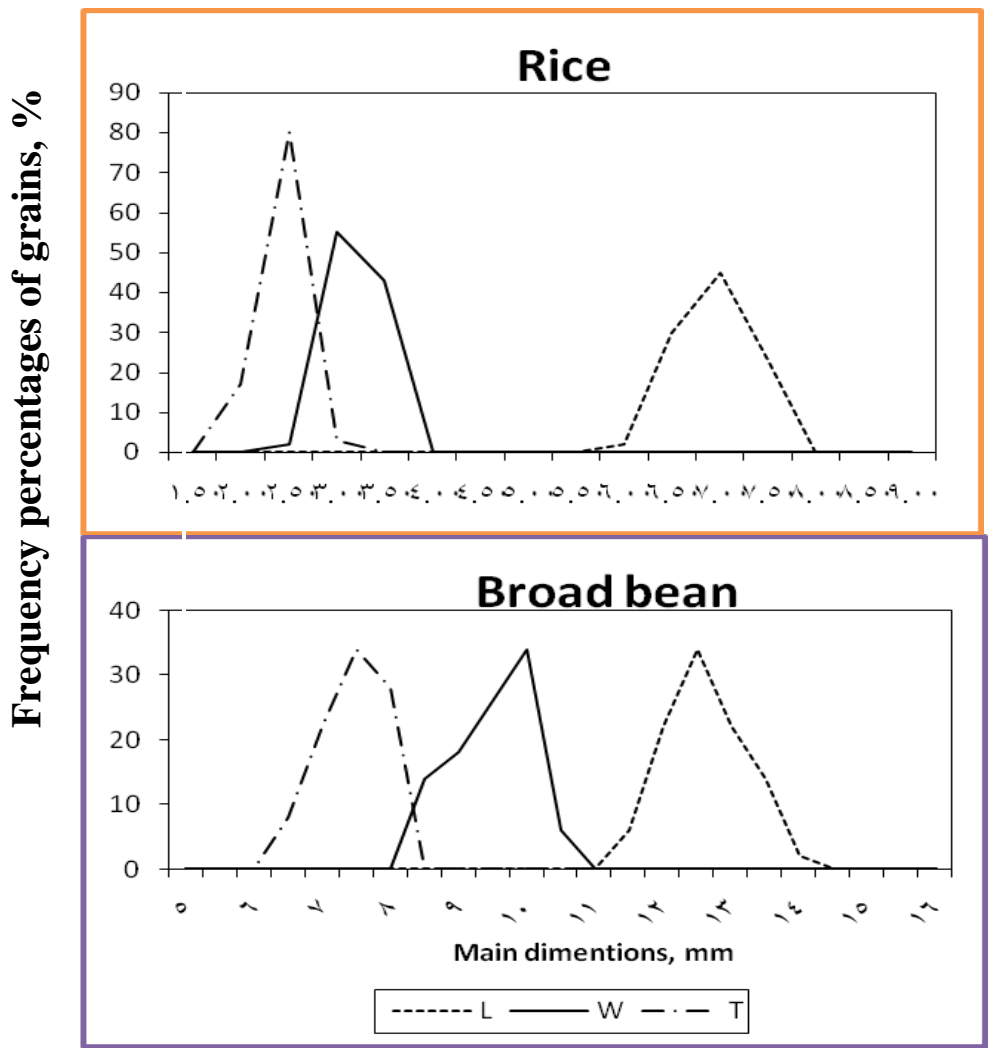

Fig. (1): Frequency of main dimensions for different type of grain crops. 
Table (2): Statistical analysis for mechanical and aerodynamic properties of the studied grains.

\begin{tabular}{|c|c|c|c|c|c|}
\hline \begin{tabular}{|l} 
Main \\
statistical \\
values \\
\end{tabular} & $\begin{array}{c}\text { Hardness, } \\
\mathbf{N}\end{array}$ & $\begin{array}{c}\text { Friction angle, } \\
\text { degree }\end{array}$ & $\begin{array}{c}\text { Repose } \\
\text { angle, } \\
\text { degree }\end{array}$ & $\begin{array}{c}\text { Grain } \\
\text { T.V., m/s }\end{array}$ & $\begin{array}{l}\text { Impurities } \\
\text { T. V., } \mathrm{m} / \mathrm{s}\end{array}$ \\
\hline \multicolumn{6}{|c|}{ Paddy Rice Giza 176 variety } \\
\hline Ave. & 38.99 & 23 & 30 & 20 & 5 \\
\hline S.D & 4.903 & 0.943 & 0.816 & 1.491 & 1.155 \\
\hline C.V,\% & 0.126 & 0.041 & 0.027 & 0.075 & 0.231 \\
\hline \multicolumn{6}{|c|}{ Broad Bean Giza 40 variety } \\
\hline Ave. & 225.4 & 17 & 26 & 75 & 15 \\
\hline S.D & 29.632 & 1.155 & 1.155 & 1.333 & 1.155 \\
\hline C.V,\% & 0.131 & 0.068 & 0.044 & 0.018 & 0.077 \\
\hline
\end{tabular}

The average of the angle of friction and repose (degree ) were ( 23 and 17)) and ( 30 and 26) for rice and broad bean grains, respectively. as shown in Fig (2)

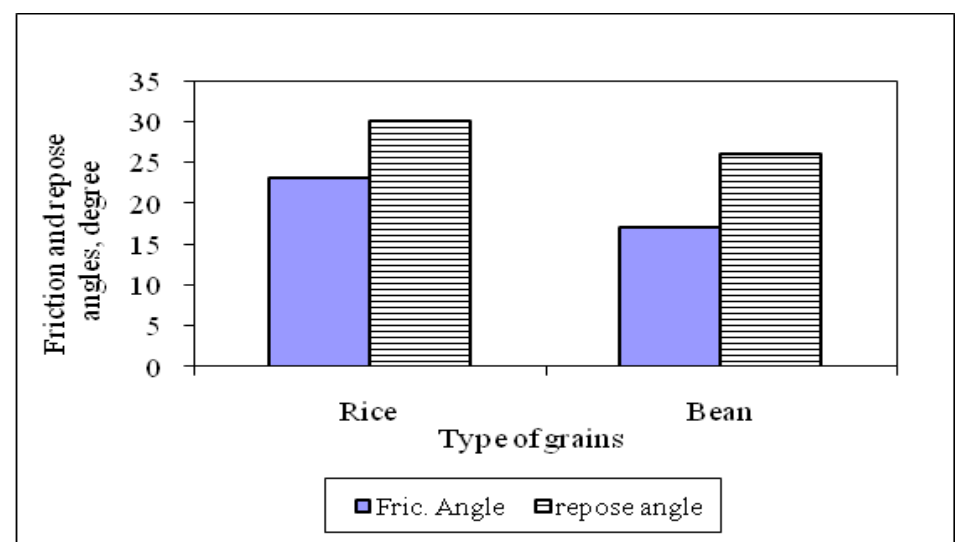

Fig. (2): The Friction and repose angles of grains.

\section{4- Relation between the measured visible laser projection area and the calculated surface area:}

Table (3) showed that calculation of factor related between projection surface area and calculated surface area, it is possible to use projection area value directly with correlation factors of 1.022 and 1.109 for paddy rice and broad bean grains, respectively for design holes of sieves and grading machine. It was noticed that the projection area method using visible laser was faster than the mathematical equations, which depends on main dimensions. 
Table (3) : Calculation of correlation factors between projection surface area and empirical surface area.

\begin{tabular}{|l|c|c|c|}
\hline \multirow{2}{*}{$\begin{array}{l}\text { Varieties } \\
\text { grains }\end{array}$} & \multicolumn{3}{|c|}{ Equation method of surface area, $\mathbf{~ m m}^{2}$} \\
\cline { 2 - 4 } & Empirical & Correlation factor & Laser \\
\hline Paddy rice & 15.8 & 1.022 & 16.15 \\
\hline Broad bean & 97.7 & 1.109 & 108.41 \\
\hline
\end{tabular}

\section{5- Effect of dimension of grains on sieves design:}

Table (4) showed that using maximum of grains dimensions to design holes of sieves which used to cleaning and separating of grain. In case of the round sieves, the diameters of holes were 8.00 and $14.5 \mathrm{~mm}$ while the distance between two holes was of 6.0 and $10.7 \mathrm{~mm}$ for rice and broad bean, respectively. Meanwhile, in case of slot holes of sieves, the area of holes (length (h1) X width (h2)) of were $(8.0 \times 3.5)$, and $(14.5 \times 10.5 \mathrm{~mm})$ while the areas between two slot holes were (length (e1) X width (e2)), $(7.5 \mathrm{X}$ $2.5)$ and $(18.25 \times 5.0 \mathrm{~mm})$ for rice and broad bean grains, respectively.

Table (4): Parameter affecting sieves selection for different grains.

\begin{tabular}{|l|c|c|c|c|c|c|c|c|c|}
\hline $\begin{array}{l}\text { Type } \\
\text { of } \\
\text { grain }\end{array}$ & $\mathbf{Q}, \mathbf{k g} / \mathbf{h}$ & $\mathbf{L}_{\mathbf{s}}, \mathbf{c m}$ & $\mathbf{B}_{\mathbf{s}}, \mathbf{c m}$ & $\mathbf{q}_{\mathbf{F}}, \mathbf{k g} / \mathbf{h}$ & $\mathbf{q}_{\mathbf{B}}, \mathbf{k g} / \mathbf{h}$ & $\mathbf{F}, \mathbf{~ m}^{\mathbf{2}}$ & $\mathbf{B}_{\mathbf{s}}, \mathbf{m m}$ & $\mathbf{L}_{\mathbf{s}}, \mathbf{m m}$ & $\mathbf{L}_{\mathbf{s}} / \mathbf{B}_{\mathbf{s}}$ \\
\cline { 2 - 10 } & 1000 & 110 & 30 & 30 & 333 & 0.33 & 300 & 1100 & 3.6 \\
\hline Rice & 700 & 110 & 30 & 21 & 233 & 0.33 & 300 & 1100 & 3.6 \\
\hline Bean & 70 & \multicolumn{8}{|c|}{ Distribution of round holes on sieves. } \\
\hline & $\mathrm{L}, \mathrm{mm}$ & Dia., $\mathrm{mm}$ & $\mu$ & $\mathrm{r}, \mathrm{mm}$ & $\mathrm{m}, \mathrm{mm}$ & $2 \mathrm{~m}, \mathrm{~mm}$ \\
\hline Rice & 7.70 & 8.00 & 0.30 & 4.00 & 3.00 & 6.00 \\
\hline Bean & 14.20 & 14.50 & 0.30 & 7.25 & 5.35 & 10.70 \\
\hline & \multicolumn{8}{|c|}{ Distribution of slot holes on sieves. } \\
\cline { 2 - 9 } & $\mathrm{L}, \mathrm{mm}$ & $\mathrm{h} 1, \mathrm{~mm}$ & $\mathrm{~W}, \mathrm{~mm}$ & $\mathrm{~h} 2 . \mathrm{mm}$ & $\mathrm{e} 1, \mathrm{~mm}$ & $\mathrm{e} 2, \mathrm{~mm}$ \\
\hline Rice & 7.70 & 8.00 & 3.40 & 3.50 & 7.50 & 2.50 \\
\hline Bean & 14.20 & 14.50 & 10.30 & 10.50 & 18.25 & 5.00 \\
\hline
\end{tabular}

\section{CONCLUSION}

From the obtained results the following conclusions are derived:

1 - It is possible using light projection area value directly for paddy rice and broad bean grains instead of mathematical surface area.

2- In case of the round hole of sieves, the diameter of holes were 8.00 and $14.5 \mathrm{~mm}$, and the distances between two holes were of 6.0 and $10.7 \mathrm{~mm}$ for rice and broad bean, respectively. Meanwhile, in case of slot holes of

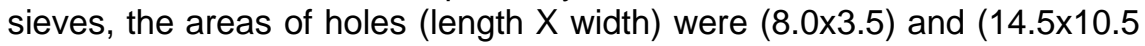
$\mathrm{mm}$ ) while the areas between two slot holes were (length $X$ width) was of $(7.5 \times 2.5)$ and $(18.25 \times 5.0 \mathrm{~mm})$ for rice and broad bean, respectively.

3 - The highest mean values of terminal velocity of grains were 20 and 75 $\mathrm{m} / \mathrm{s}$ for rice and broad bean, respectively. But, for the impurities of grain they were 5 and $15 \mathrm{~m} / \mathrm{s}$. for rice and broad bean, respectively.

4- The friction angle of grain hopper was $23^{\circ}$ for rice and $17^{\circ}$ for broad bean for steel surface, respectively.

5- The slop angle of the sieve toward horizontal plan was $5^{\circ}$ for rice and $7^{\circ}$ for broad bean, respectively. 


\section{REFERENCES}

Asoegwu, S., O. Ohanyere, O. Kanu and C. Iwueke. (2006). Physical properties of african oil bean (Pentaclethra macraphylla). Agricultural Engineering International: the CIGR Ejournal. Manuscript FP 05006. Vol VII.

Awady, M. N. and A. S. Sayed (1994). Separation of peanuts seeds by air stream, MSAE., 11 (1) : 137-147.

Buyanov, A.I. and B.A.Voronyuk.( 1985 ). Physical and mechanical properties of plant, fertilizers and soils. Amerind Publishing Co PVT..LTD. New Delhi-Bombay - Calcutta- New York.

Chakraverty, A. (1987). Post harvest technology of cereals, pulses and oil seeds (revised edition), Oxford and IBH Publishing Co. PVT LTD. New Delhi. Bombay, Calcutta.

Dilday, R.H. (1987). Influence of thresher cylinder speed and grain moisture at harvest on milling yield of rice. Arkansas Academy of Science 41:35-37.

El-Raie, A. E., (1981). Some physical characteristics of Egyptian wheat concerning the design and selection of separating devices, Res. Bull. Cairo Univ. No. 358.

El-Raie, A.E.S (1987). Study of shelled corn related to mechanical separation. Misr. J. Ag. Eng., 4 (1) : 36- 52.

El-Raie, A.E.S.; N. A. Hendawy and A.Z. Taib (1996). Study of physical and engineering properties for some agricultural products. Misr. J. Ag. Eng., 13 (1) : 211-226.

El-Raie, A.E.S.; H. E. Hassan, A.A. Abd El-Rahman and Y.B. Abd El-Hay. (2004). A laser optical method for measuring some physical properties and inference surface area equation of faba bean. The is th Conference of Miser. Society of Agr. Eng., 4-5 october :25 - 40

Gomez, K.A. and A.A.Gomas.( 1984). Statistical for agricultural researches. John Wiley and Sons.Inc.,New York.

Helmy, M. A. (1995). Determination of static friction coefficient of some Egyptian agricultural products on various grains. Misr. J. Ag. Eng., 12 (1): 276-282.

Ministry of Agricultural and Land Reclamation (2013). Study of Important Indicators of The Agricultural Statistics Crops. Economic Affairs Sector.

Mohsenin, N.N. (1986). Physical Properties of Plant and Animal Materials (2nd ed.). Gordon and Breach Science, Pub., New York. Pp: 88-90

Molenda, M., J. Horabik, I.J. Ross and M. D. Montross. (2002). Friction of wheat: Grain on grain and on corrugated steel. Trans. of the ASAE. 45(2): 415-420.

Natsuga, M., S. Kawamura and K. Itoh, (1992). Precision and accuracy of near-infrared reflectance spectroscopy in determining constituent content of grain (in Japanese with English abstract). Journal of the Japanese Society of Agricultural Machinery 54 (6), 89_94. 
Regulations of Trade Ministry. 1992. No. 635. Concerning the monitoring of exports of citrus fruits. Quality specifications for exported fresh fruits and vegetables. Ministry of Economy and Foreign Trade General Organization for exports and imports control. (110-124).

Simonian, K.; Y. Yiljep, and O. Mudiare. (2006). Modeling the cleaning process of a stationary sorghum thresher. Agricultural Engineering International: the CIGR Journal Manuscript PM 06012 Vol. VIII.

Zewdu, A. D. (2004). Untersuchungen zur Leistungssteigerung der Reinigungsanlage eines Maehdreschers durch zusaetzlichen Querschwingungen (Investigations into performance improvement of combine cleaning shoe through additional lateral oscillations), $\mathrm{PhD}$ Diss. Technical University of Dresden, Germany. Pp. 125.

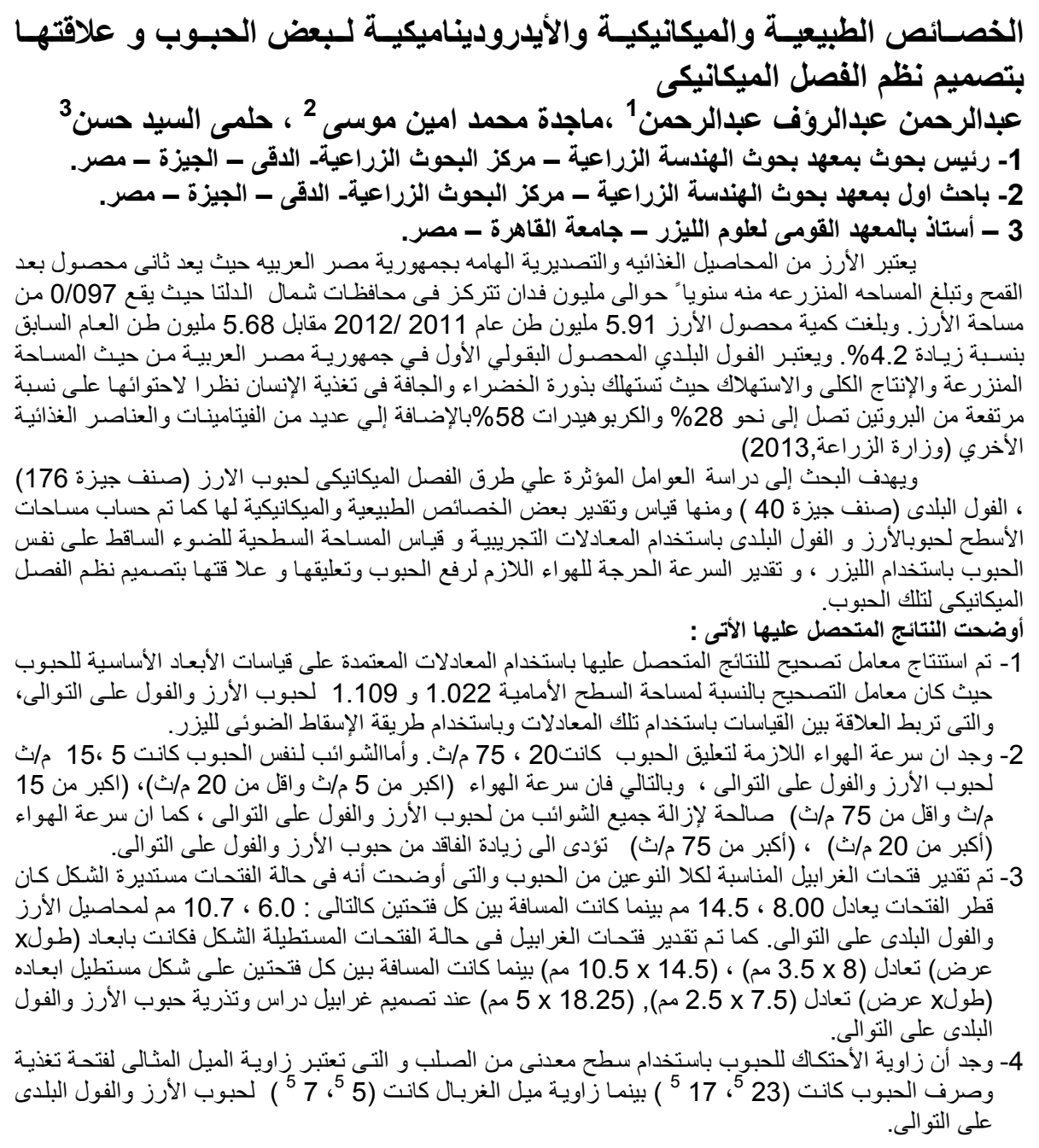


Abd El-Rahman, A. A.et al.

$\begin{array}{lllllllllll}5 & 6 & 7 & 9 & 10 & 11 & 12 & 13 & 14 & 15 & 16\end{array}$

$1.53 .03 .54 .04 .55 .05 .5 \quad 6 \quad 06.57 .07 .58 .08 .59 .0$

1850 